\title{
American Outlaws in Australia
}

\author{
Bruce $\operatorname{Tranter}^{1} \&$ Jed Donoghue ${ }^{1}$ \\ ${ }^{1}$ University of Tasmania, Tasmania \\ Correspondence: Bruce Tranter, School of Social Sciences, University of Tasmania, Private Bag 22, Hobart, \\ Tasmania, 7001. E-mail: Bruce.Tranter@utas.edu.au
}

Received: June 1, 2013 Accepted: June 17, 2013 Available online: June 24, 2013

doi:10.11114/ijsss.v1i2.158

URL: http://dx.doi.org/10.11114/ijsss.v1i2.158

\begin{abstract}
An aspect of the diffusion of American popular culture is examined in this research drawing upon national survey data. Measuring Australians' knowledge of American and Australian outlaws, we found that Jesse James and Billy the Kid are better known in Australia than any of the local outlaws, or bushrangers, with the exception of Ned Kelly. While a relatively large proportion of Australians identified Ned Kelly, Ben Hall, Jesse James and Billy the Kid as outlaws, few identified other Australian 'outlaws'. Social background and political ideology is associated with greater knowledge of outlaws. Men, baby boomers and their predecessors, those born in Australia or the UK, those with a basic secondary level education and those identifying as left on the political spectrum are the most knowledgeable. This Australian study suggests that outlaws such as Jesse James and Billy the Kid are not just national folk heroes, but recognised globally. Promoted by visual and print media they have transcended their outlaw heritage to represent romanticised notions of freedom, loyalty and the 'underdog', regardless of the historical facts surrounding their lives and deaths.
\end{abstract}

Keywords: outlaws, bushrangers, social bandits, Jesse James, Ned Kelly, Australia

\section{Introduction}

The penetration of popular American cultural figures, American outlaws, is examined in this research. Outlaws form part of the American mythscape, that 'temporally and spatially extended discursive realm wherein the struggle for control of peoples memories and the formation of nationalist myths is debated, contested and subverted incessantly' (Bell, 2003, 66). While by no means respected by all, outlaws such as Jesse James are to an extent 'celebrated' in other countries as well, including Australia, particularly by people who spent their formative years watching American western movies and 'spaghetti westerns'. Television programs and films that romanticized the American West were particularly popular during the 1950s and 1960s and re-emerge from time to time as a film genre (Cawelti, 1984). A generation or so ago, Australian children like their North American counterparts could be found acting out 'western' fantasies, playing 'cowboys and Indians', where the 'Indians' were typically viewed as 'bad' and shot by 'good' cowboys or cavalry.

The myths that grew up around 'wild west' outlaws have been the focus of many studies of American folklore (e.g. White, 1981, Brown, 1993, Stiles, 2002). The characteristics of outlaws, according to Seal (1996) include ten recurring themes, or 'motifs' shared in lore across a variety of cultures. These include the outlaw as a 'friend of the poor', as having been 'oppressed' and 'forced into outlawry', but also exhibiting heroic traits, such as 'bravery', being 'generous' and 'courteous', avoiding 'unjustified violence', being a 'trickster' who evades capture, who is ultimately 'betrayed' but in a sense 'lives on after death' (Seal 1996, 11). Rumours that Jesse James and Billy the Kid faked their own deaths, and survived to escape justice, remain popular in America (Yeatman, 2000). Since their reported deaths several people have even claimed to be Jesse James or Billy the Kid, with negative DNA tests failing to dispel such rumours (Yeatman, 2000). While such claims are perhaps more frequently associated with American outlaws, similar rumours emerged in relation to Dan Kelly and Captain Thunderbolt in Australia.

In a similar vein to Seal (1996), Cashman (2000, 205-209), identifies 'innocent beginnings...supernatural protection...chivalry...non-violence...guile, bravado...fair play...robbing the rich to give to the poor...self-sacrifice' and being betrayed by trusted others as common themes in Irish outlaw mythology. Many of these themes have been applied in portrayals of the Australian outlaw Ned Kelly: 
a man wronged by the police and the government...brave, clever, an outstanding bushman who outsmarts the police at almost every turn, who offers no violence to the poor and weak and eventually 'dies game' (Davey and Seal, 2003, 168-9)

Accounts of Ned Kelly, like the outlaws Jesse James and Billy the Kid are imbued with tales of bravery, a propensity for risk taking, and, in some cases, as a champion against injustice (Hobsbawm, 2000). As West $(2001,137)$ explains, "[I]t is not simply just the manner of the Robin Hood archetype that transforms criminals and outlaws into social bandits. It is the way they are interpreted to defy rules and capture through daring and cunning". According to Eric Hobsbawm (2000), such heroes also need the support of their 'oppressed' countrymen and women, who typically feed and hide these friends of the common people in order for them to evade capture.

\subsection{Outlaw Myths}

Myths that have grown up around outlaws are not just limited to Australia and the USA. Cashman $(2000,193)$ has shown that in Ireland, the representation of outlaws in 'folklore and popular literature provides a valuable perspective on the intersections of culture and politics and especially the development of national identity and nationalism', while Hobsbawm (2000) has documented similar cases of 'social bandits' in countries such as France, Germany, Spain, Italy, and a variety of countries in Eastern Europe and Northern and Southern America. Outlaw myths are not only of interest to scholars of folklore and history; they reflect the values of, and nostalgia for a lost 'golden age' (Smith, 1996), when traditional masculine values and pride in one's nation was allegedly far more common than it is in contemporary nation states.

Seal $(2002,154)$ claims 'the noble robber or 'Robin Hood' figure who redresses the political and economic wrongs done to the poor by the rich and powerful, is a cultural constant throughout the world, appearing in many guises in many nationalities'. Descriptions of the best known Australian bushranger, Ned Kelly by Jones (1995), suggest that he shared many of the characteristics of the 'rural bandit', supported as he was by large networks of relatives, friends and sympathisers. Many outlaws reflect elements of oppositional politics to the authorities who pursued them, as well as class, ethnic and religious based inequalities (see Jones, 1995, Seal, 1996, Hobsbawm, 2000). Yet how well known are American outlaws like Jesse James and Billy the Kid compared to their Australian counterparts, the bushrangers?

\subsection{Jesse James, Outlaw or Hero?}

A brief account of probably the best known American outlaw serves to situate our study of American outlaws in Australia. Robin Hood-like outlaw traditions persist in many advanced industrial societies. Jesse James is particularly prominent, as he has remained in the public eye as the subject of movies, television documentaries and scholarly and fictional literature (Anderson, 1986, White, 1981, Brown, 1993). Outlaw heroes such as James personify the globalisation of American popular culture, promulgated through mass media, particularly film and television, but also through western books, comics and songs (White, 1981, Anderson, 1986). James (along with Billy the Kid) is a $19^{\text {th }}$ century American that many Australians are likely to have at least heard about, even though most may have scant knowledge of his actual biography. On the other hand, Wyatt Earp, Wild Bill Hickok and Pat Garrett are portrayed as 'heroic' lawmen who kept frontier towns safe for their fellow citizens and big business, although the veracity of such accounts is questionable (Brown, 1993).

Similar to Ned Kelly in Australia, Jesse James is a heroic but divisive figure in the United States. The James-Younger gang had its origins in the Confederate guerrillas of the American Civil War who were recruited from the economic and social elite of Jackson and neighbouring counties (White, 1981, Stiles, 2002). The leading members of the gang were ex-guerrillas with similar social origins. Colonel Henry Younger, the father of the Younger brothers was a large land holder in Jackson and Cass counties prior to the American Civil War and his wife's father a member of the Missouri legislature, while Jesse and Frank James' father was a Baptist minister who in 1850 owned a 275 -acre farm (White, 1981, 394). ${ }^{\mathrm{i}}$

According to Stiles (2002), Jesse James and older brother Frank were raised in a pro-slavery household in Missouri. Jesse was a child soldier who at the age of sixteen became a 'bushwhacker' by joining the Confederate guerrillas who terrorized the American Border States. After the Civil war, James continued his campaign of robbery and murder in the era of reconstruction. His daring raids, partisan pronouncements, letters to newspapers, and alliance with the founder and editor of the Kansas City Times, John Newman Edwards, placed him at the forefront of the former Confederates' bid to recapture political power in Missouri. ${ }^{\text {ii }}$ Yet Stiles (2002) claims James was a foul-mouthed killer who lined his pockets in the name of the Confederate cause, motivated by the 'struggle' against the freedom of former slaves. Jesse James was not an apolitical, beneficent Robin Hood-like hero of legend, but a man who used violence for a political cause. In fact Stiles (2002) maintains that in his 
political consciousness and alliance with a propagandist and power broker (Edwards), and in his efforts to win media attention for his crimes, Jesse James was a forerunner of the modern terrorist. Nevertheless, James remains a hero of the American neo-Confederate movement.

\subsection{Outlaws and Politics}

The political aspects of the James-Younger gang activities are often neglected in Hollywood accounts. As White $(1981,397)$ maintains, public support of social bandits can only endure where belief in the honesty and competency of public law enforcement has been seriously eroded. This was the case in post-war Missouri in the 1890s, where ex-Confederates soldiers hated and feared Union sheriffs, who they believed used their office to settle old scores from the war; and with the 'unionist' state militia who were called up to maintain order, they were regarded as plunderers and freebooters. ${ }^{\text {iii }}$ In the post-civil war era, outlaws looted banks and railroads whose 'rapacious' economic activities caused resentment among farmers, ranchers, and local townspeople (Brown 1993, 7).

White $(1981,396)$ argues that local government officials interested in attracting capital to Missouri blamed the James-Younger gang for discouraging investment and immigration. At the time, Governor Crittenden and Senator Carl Schurz of Missouri defended the assassination of Jesse James as ridding the state of 'a great hindrance to its prosperity and as likely to give an important stimulus to real estate speculation, railroad enterprise, and foreign immigration' (White, 1981, 396). Frank and Jesse James portrayed themselves as local heroes; Frank even crediting his robberies with maintaining local prosperity because they frightened eastern capital out of Jackson County and thereby kept it free of mortgage and land speculation. In 1897, well after his outlaw career was over, Frank James (White, 1981, 396) declared: 'If there is ever another war in this country, which may happen, it will be between capital and labour, I mean between greed and manhood, and I'm as ready to march now in defence of American manhood as I was when a boy in the defence of the South.' The elder James brother was not alone in his jump to the left; James Younger also became a socialist while in prison.

Notably, Brown $(1993,7)$ identifies two types of 'gunfighter' in the American west. Those he refers to as 'incorporation gunfighters' lined up on the side of big business and investment in regional land conflicts. Incorporation gunfighters are exemplified by Wild Bill Hickok and Wyatt Earp, both of whom were northerners and staunch members of the Republican Party. The local opposition, Brown refers to as 'resister gunfighters' who regularly used violence in attempts to reject northern incorporation. The latter often claimed southern or Texan roots and professed loyalty to the Democratic Party. As 'resisters', both Jesse James and to a lesser extent, Billy the Kid, fit Hobsbawm's description of 'social bandits'.

The political divides exhibited by Republican 'incorporation' and Democrat 'resister' gunfighters in the USA are reminiscent of the Australian case of Ned Kelly. Kelly is seen as an important symbol of national identity by a majority of Australians (Tranter \& Donoghue, 2010, 2008). The political left, and those aligned with progressive political parties such as Labor and the Greens are far more likely than those on the right or conservatives to hold such views, and far more likely to positively identify with Kelly as exhibiting the qualities associated with Hobsbawm's social bandit.

\subsection{Research Aims}

In this research we attempt to assess the 'heroic' western outlaw as comprising one element of the diffusion of American culture (see Bell \& Bell, 1998). We examine Australian's knowledge of outlaws by asking survey respondents to name four American outlaws. Several questions are of interest to us. First, how well known are American outlaws in contemporary Australia? Which outlaws are the most widely known, and perhaps more importantly, are Australians as able to identify American outlaws as they are the home grown Australian outlaws known as bushrangers? Second, to what extent does socio-demographic background influence knowledge of outlaws? For example, how is knowledge of particular American outlaws related to characteristics such as gender, age, education level and country of birth? We expect men to be more knowledgeable of outlaws than women, older people to be more able to identify outlaws than younger people and educational achievement to have a positive association with outlaw knowledge. Location in rural areas is expected to be associated with greater interest in, and therefore knowledge of rural bandits. The association of Ned Kelly with a working class, left of centre political ideology and progressive political parties demonstrated by Tranter and Donoghue $(2010,2008)$ is also expected here in relation to outlaw knowledge. ${ }^{\text {iv }}$ In addition, being generally well informed about a range of social and political issues is expected to increase knowledge of outlaws. 


\section{Method}

\subsection{Data}

This research is based on survey questions we included in the 2005 Australian Survey of Social Attitudes (AuSSA), a nationally representative sample of Australian adults aged 18 and above (see Wilson, Gibson, Meagher, Denemark, Western, 2006). The 2005 AuSSA is the second in a biennial series of surveys administered by a team of researchers based at the Australian National University. The 2005 AuSSA had a split sample design where an identical set of core questions were included in each survey, while researchers were able to purchase questionnaire space in which to include their own question items. Our questions were included in a sample with 1,914 cases, with a response rate of $42 \%$, which is comparable with other Australian academic attitudinal surveys of the time, such as the 2004 Australian Election Study (see Bean, McAllister, Gibson, Gow, 2005).

The following questions in the 2005 Australian Survey of Social Attitudes pertain to our study of Australian and American outlaws:

Bushrangers roamed the countryside during the early period of European settlement in Australia. Please write the names of four bushrangers below.

Outlaws were also common in the United States of America in earlier times. Please write the names of four outlaws in the spaces below.

\subsection{Advantages and Limitations}

The research strategy adopted here enables us to address some of our research questions better than others. A major advantage of the survey approach is that it allows inferential claims to be made about Australian adults based upon the sample results, so it is possible to generalise the findings to the Australian population. Multivariate analytic techniques are used to examine the associations or relationships between the dependent variables (i.e. knowledge of bushrangers and outlaws) and socio-demographic factors (independent variables) while simultaneously adjusting for correlation between the independent variables.

Our approach also has its limitations, however, as while it allows estimations to be made regarding the proportion of Australians correctly identifying outlaws and bushrangers, less useful data are available to account for variations in cultural background. That is, the AuSSA contains a variety of demographic variables, but does not include data on what Bourdieu (1984) refers to as 'cultural consumption' - questions regarding the consumption of literature, television and film, for example. However, the survey does include items that pertain to news consumption, in the form of the type of media accessed for news. A dummy variable is constructed from items that measure the consumption of news in a general sense. ${ }^{\mathrm{V}}$ A further question gauges basic knowledge of Australian politics. ${ }^{\text {vi }}$ The latter is a useful proxy of civics education (McAllister, 1998) and is therefore expected to be correlated positively with an ability to identify outlaws and bushrangers.

\section{Results}

\subsection{Best Known Outlaws and Bushrangers}

To begin, responses to the two survey questions are summed to establish the 4 best known American outlaws and Australian bushrangers (Table 1). It is important to note that these responses do not tally to $100 \%$, but are cumulative percentages of responses to each of the four possible question response categories. That is, responses are summed for each outlaw or bushranger named as first, second, third or fourth choice.

Jesse James (46\%) emerges as by far the most frequently named outlaw. While it is perhaps not surprising that many Australians can identify James, the results provide a gauge of the extent of their knowledge. The next best known outlaw - Billy the Kid - was named by $33 \%$ of respondents in total. Thereafter, a substantial drop in recognition occurs to Butch Cassidy (12\%) and the Sundance Kid (6\%), famously represented in the 1969 film of the same name starring Paul Newman and Robert Redford. The other James gang members - including Jesse's older brother Frank - also fared poorly in the survey. 'Wild Bill' (James Butler) Hickok was identified by 5\% of the sample as an outlaw, as were Doc Holliday and Wyatt Earp by approximately 3\%. In reality these lawmen allegedly worked both sides of the law (Carnes 1996). 
Table 1. Best Known Outlaws and Bushrangers (per cent)

\begin{tabular}{lr}
\hline Outlaws & \\
Jesse James & 46.4 \\
Billy the Kid (William Bonney) & 33.3 \\
Butch Cassidy (Robert LeRoy Parker) & 11.8 \\
Sundance Kid (Harry Longbaugh) & 6.3 \\
'Wild Bill' (James Butler) Hickok & 5.0 \\
Doc Holliday & 4.5 \\
Frank James & 2.7 \\
Wyatt Earp & 2.5 \\
Cole Younger & 0.9 \\
& \\
Bushrangers & \\
Ned Kelly & 80.4 \\
Ben Hall & 28.9 \\
Captain Thunderbolt (Frederick Ward) & 12.4 \\
'Mad' Dan Morgan & 12.0 \\
Dan Kelly & 11.0 \\
Captain Moonlite (Andrew George Scott) & 8.5 \\
Frank Gardiner & 5.5 \\
Steve Hart & 2.8 \\
Captain Midnight (Thomas Smith) & 2.5 \\
Joe Byrne & 2.5 \\
\hline
\end{tabular}

Source: Australian Survey of Social Attitudes (2005)

In contrast, $80 \%$ of Australians named Ned Kelly as a bushranger and 29\% identified Ben Hall. The next best known bushrangers were Captain Thunderbolt and Dan Morgan with around 12\% of the cumulative responses. These results show that Jesse James and Billy the Kid are recognisable to more Australians than any of their home grown outlaws, with the exception of the armoured outlaw, Ned Kelly!

\subsection{Knowledge of Outlaws and Bushrangers}

In Table 2 we present responses to the two survey questions to measure overall knowledge of outlaws and bushrangers. Drawing upon a variety of literature on outlaws and bushrangers (e.g. Nixon, 1982) we classified responses as correctly or incorrectly identifying actual outlaws. The results indicate that approximately 40 per cent of Australians could not correctly name any American outlaws at all, compared to 18 per cent who could not identify any bushrangers. Twenty five per cent correctly identified one American outlaw, compared to $28 \%$ who named only one Australian bushranger, quite similar results.

Table 2. Outlaws and Bushrangers Correctly Identified by Australian Adults (per cent)

\begin{tabular}{lcc}
\hline & Outlaws & Bushrangers \\
\hline None & 40.2 & 17.5 \\
1 & 24.6 & 27.5 \\
2 & 16.3 & 19.0 \\
3 & 9.6 & 12.6 \\
4 & 9.4 & 23.4 \\
Total & $(1914)$ & $(1914)$ \\
\hline
\end{tabular}

Source: Australian Survey of Social Attitudes (2005)

Knowledge of bushrangers was more evenly spread than knowledge of American outlaws - for the latter knowledge declined in a monotonic fashion. At the high end of the scale, only 9 per cent of respondents could identify four American outlaws compared to 23 per cent who correctly identified four bushrangers. When these results are examined alongside those in Table 1, it seems that Australians' knowledge of outlaws tends to be limited to a few high profile figures, notably Jesse James and Billy the Kid. However, it is important to point out that our question design diminishes the likelihood of several outlaws or bushrangers being identified by a large proportion of the sample, as we constrained possible responses to only 4 outlaws and bushrangers. The popularity of two outlaws - particularly Jesse James and Billy the Kid - limits the magnitude of subsequent responses. The same can be said of the bushranger scale due to the much higher profile of two Australian 
bushrangers - Ned Kelly and Ben Hall. Some respondents also stretched the boundaries of what constitutes an 'outlaw', identifying politicians such as former Presidents George Bush and Ronald Reagan, and 'western' film actors Clint Eastwood and John Wayne.

\subsection{Social Background}

To illustrate the impact of social background on Australian's choice of the 4 best known outlaws and bushrangers, the two scales presented in Table 2 are modelled as dependent variables with ordinary least squares regression models in Table 3. The scales range from zero (representing no outlaws or bushrangers correctly identified) to 4 (where respondents could name 4).

Generational differences are apparent, with the oldest respondents able to name more bushrangers than the 35 and under reference category. Recognition of outlaws is strongest among the baby boomer generation. Secondary schooling also influences knowledge. However, while the effect was positive for bushrangers, tertiary education had a weak and non-significant effect for outlaws at the $95 \%$ level of statistical significance. Interestingly, those who completed year 10 tend to do better on these questions than those with more (or less) secondary schooling. Identifying with the left of the political spectrum is associated with higher scores on both the outlaw and bushranger scales, while knowledge of politics is also correlated with greater knowledge of American and Australian outlaws. Controlling for other factors, men were more knowledgeable than women on the outlaw scale, consistent with gender based knowledge of politics (Tranter, 2007).

Table 3. Social Background on Knowledge of Bushrangers and Outlaws (OLS)

\begin{tabular}{|c|c|c|c|c|}
\hline & \multicolumn{2}{|c|}{ Outlaws } & \multicolumn{2}{|c|}{ Bushrangers } \\
\hline & $\mathrm{b}$ & $\beta$ & $\mathrm{b}$ & $\beta$ \\
\hline Intercept & -0.02 & & 0.003 & \\
\hline Men & $0.3 * * *$ & 0.10 & 0.07 & 0.02 \\
\hline Pre WWII & $0.3^{*}$ & 0.09 & $0.7 * * *$ & 0.21 \\
\hline Boomers (1946-59) & $0.4 * * *$ & 0.14 & $0.6 * * *$ & 0.19 \\
\hline Gen X (1960-1970) & $0.3 * *$ & 0.10 & $0.4 * *$ & 0.12 \\
\hline Gen Y (1970+) & 0 & - & 0 & - \\
\hline Completed Year 10 & $0.2^{*}$ & 0.07 & $0.3 * * *$ & 0.11 \\
\hline Degree & -0.1 & -0.04 & $0.2^{*}$ & 0.07 \\
\hline Australian Born & $0.5 * * *$ & 0.17 & $0.9 * * *$ & 0.26 \\
\hline UK Born & $0.6 * * *$ & 0.14 & $0.6 * * *$ & 0.11 \\
\hline Born Elsewhere & 0 & - & 0 & - \\
\hline Protestant Denomination & $0.2^{*}$ & 0.06 & $0.2^{* *}$ & 0.07 \\
\hline Rural location & -0.03 & -0.01 & $0.3 * * *$ & 0.09 \\
\hline Left $(0-4)$ political orientation & $0.2^{*}$ & 0.05 & $0.3 * * *$ & 0.08 \\
\hline Self-identified Middle Class & 0.1 & 0.03 & $0.3 * * *$ & 0.06 \\
\hline $\begin{array}{l}\text { Newspapers or Internet main } \\
\text { source of news and information }\end{array}$ & 0.1 & 0.04 & $0.2 * *$ & 0.07 \\
\hline Political Knowledge & $0.3 * * *$ & 0.10 & $0.4 * * *$ & .11 \\
\hline $\begin{array}{l}\mathrm{R}^{2} \\
\mathrm{n}\end{array}$ & $\begin{array}{l}.08 \\
(1656)\end{array}$ & & $\begin{array}{l}.15 \\
(1656)\end{array}$ & \\
\hline
\end{tabular}

Source: Australian Survey of Social Attitudes (2005)

Country of birth is also an important indicator, as being born in Australia or the United Kingdom is associated with higher knowledge on both scales. Protestants also score higher than other denominations on both scales. Finally, self-assessed class location has a clear impact, but not in the manner we hypothesised. Working class Australians are actually less knowledgeable of bushrangers than their middle class counterparts, although there is 
essentially no class effect for the outlaw dependent variable.

Those who consume news from print media or the internet have higher knowledge, but only of bushrangers, while living in a rural area is not associated with greater knowledge of American outlaws, although it is with Australian bushrangers. However, other analyses (not shown here) where the regression models in Table 3 were split by respondent sex, indicate that the models explain less variation $\left(\mathrm{R}^{2}\right)$ for men than they do for women. ${ }^{\mathrm{vii}}$ Further, a lack of age effects among men suggest that controlling for other independent variables, their knowledge of outlaws is more evenly spread across the lifecourse than it is among women; while men living in rural locations are able to identify fewer bushrangers than men living elsewhere.

\section{Discussion}

...overseas influences, particularly those originating from America, appear to be increasingly shaping Australians' tastes in a wide range of cultural domains. Nevertheless, despite these changes in cultural taste Australians of all ages retain a strong sense of a distinctive national identity (Emmison, 1997, 322).

Outlaws are not just national folk heroes but heroic figures who are recognised around the globe. Yet the myths around outlaw heroes often bear little resemblance to historical accounts. For example, regardless of the fact that in life the outlaw Jesse James was a supporter of slavery (Stiles, 2002), he has come to symbolise diametrically opposite values such as freedom and even the pursuit of justice for the downtrodden. Like Robin Hood, Jesse James has attained global fame through Hollywood films and television programs. Yet the film industry also absorbs, modifies and homogenizes 'foreign' outlaw traditions in search of products for the global market, so that not only the iconic Robin Hood, but also to a lesser extent others such as the armoured Australian bushranger Ned Kelly come to be recognized globally.

Popular movies and television programs have undoubtedly reconstructed and popularized outlaws such as Jesse James and Billy the Kid to the extent that they are household names in Australia. James has been the subject of at least twenty nine Hollywood films that have attracted a wide audience, including Jesse James Under the Black Flag (1921), True Story of Jesse James (1957) to The Long Riders (1980), and more recently American Outlaws (2001) and Jesse James: Legend, Outlaw, Terrorist (2007). Billy the Kid has also been portrayed in films including Billy the Kid (1930), The Left-Handed Gun (1958), Pat Garrett and Billy the Kid (1973) and To Purgatory (1999). viii However, the portrayal of the historical 'facts' behind these outlaws is glossed over - just as most Australians know little of the biography of its bushrangers, with the possible exception of Ned Kelly. ${ }^{\text {ix }}$

Earlier we asked how well known American outlaws are in contemporary Australia and whether Australians are as able to identify local bushrangers as they are American outlaws? The results are somewhat mixed, but indicate that with the exception of the iconic Kelly, Australians' knowledge of American outlaws appears to be higher than it is of bushrangers. The ability to identify both outlaws and bushrangers is also socially circumscribed. Younger Australians appear to know less about American outlaws than their older counterparts, although this age effect is far more marked among women than among men, perhaps reflecting the gendered audience of western movies and literature. General knowledge is of course accumulated through the process of ageing, yet it is also likely that different generations (in the sociological sense) will have greater knowledge of the social and cultural events they have experienced (Mannheim, 1952). In broad terms, the age based patterns of outlaw knowledge tallies with the ebb and flow in popularity of the American western movie genre.

Hobsbawm $(1972,504)$ maintained that 'the myth cannot be entirely divorced from the reality of banditry'. Indeed, the myths surrounding historical figures blend with the facts to create the hero, rather than describe the biography of the actual person. Social bandit folklore still resonates in advanced urbanised societies such as Australia. The universal characteristics associated with outlaw heroes - rebellious but brave, fighters against injustice and oppression, chivalrous in their treatment of women and the poor, and embodying a sense of fair play - comprise the characteristics generally associated with Jesse James in America and Ned Kelly in Australia. Students of folklore such as Hobsbawm (2000) and Seal (1996) suggest that such outlaws have universal appeal. Well, almost. In popular culture Kelly was an underdog, who stood against injustice in support of his family and friends, a rebel not afraid to break the rules, exemplified in the expression 'as game as Ned Kelly' (Hirst, 2007, 31). However, politically conservative Australians tend to revile Kelly, regarding him as a thief, bank robber and police killer who sought to undermine the law and stability of the Australian colonies (Tranter \& Donoghue, 2010). Our findings indicate that knowledge of bushrangers and outlaws is similarly divided on the left-right ideological dimension.

With the possible exception of Robin Hood, outlaw heroes will almost always be better known in their country of origin than elsewhere, notwithstanding processes of cultural globalization (Featherstone, 1990). However, $20^{\text {th }}$ and $21^{\text {st }}$ Century mass media have certainly facilitated the rapid transmission of 'outlaw culture', which has spread well beyond national boundaries, aided particularly by film and television, but also popular literature. Yet 
the globalization of culture does not merely involve the passive acceptance of foreign culture by citizens of the receiving country (Pickering, 2001, 51). By tapping themes that resonate globally, like the rebellious hero, 'foreign' cultural artifacts are absorbed and assimilated. It is also important to acknowledge that the transmission and assimilation of American 'outlaw culture' (or any form of culture) is not a one way street. To an extent it also flows from other countries (including Australia) to the USA. ${ }^{x}$ Seal $(1996,16-17)$ argues that in Australia, Ned Kelly 'has transcended the status of local hero and even that of folk hero to become a truly national hero'. Our research provides empirical support for the claim that Jesse James, like Robin Hood, is an outlaw hero who has achieved very broad, perhaps global recognition.

\section{Conclusion}

Few people would contest the claim that Ned Kelly is Australia's best known bushranger and for many a national icon who symbolises aspects of the national identity (Tranter and Donoghue, 2010). This research confirms Jesse James as another outlaw hero, who is better known in Australia than any bushranger apart from Ned Kelly. As portrayed in popular cultural accounts, James and Kelly were both underdogs who stood against injustice in support of their family and friends, rebels not afraid to break the rules, brave men with a 'hidden' political agenda. While Ned Kelly was a closet republican of Irish descent suffering under English colonial rule (Jones, 1995), James was a pro-slavery Democrat living in a divided nation after the American civil war (Stiles, 2002). The fact that both of these men endure as 'heroes' in their respective nations and are famous well beyond, is testament to the enduring power of folk traditions and the capacity of mass media to create and propagate powerful myths.

\section{Acknowledgement}

We thank the anonymous reviewers, and thank Mark Western for suggesting we extend our study of Australian bushrangers to consider American outlaws as well.

\section{References}

Anderson, C. (1986). Jesse James, the Bourgeois Bandit: The Transformation of a Popular Hero. Cinema Journal, 26(1), 43-64. http://dx.doi.org/10.2307/1224986

Bean, C., McAllister, I., Gibson, R., \& Gow, J. (2005). Australian Election Study, 2004 User's Guide for the Machine-readable Data File (ASSDA Study 1079). Canberra, Australian National University.

Bell, D. (2003). Mythscapes: Memory, Mythology, and National Identity. British Journal of Sociology, 54(1), 63-81. http://dx.doi.org/10.1080/0007131032000045905

Bell, P., \& Bell, R. (1998). Americanisation and Australia. Sydney, UNSW Press.

Bourdieu. (1984). Distinction: A Social Critique of the Judgment of Taste, Cambridge MA: Harvard University Press.

Brown, R. M. (1993). Western Violence: Structure, Values, Myth. The Western Historical Quarterly, 24(1), 4-20. http://dx.doi.org/10.2307/970005

Carnes, M. (1996). Past Imperfect: History According to the Movies. New York, Henry Holt \& Co.

Cashman, R. (2000). The Heroic Outlaw in Irish Folklore and Popular Literature Folklore, 111(2), 191-215.

Cawelti, J. (1984). The Six-Gun Mystique ( $2^{\text {nd }}$ edition). Bowling Green, Ohio, Bowling Green State University Popular Press.

Davey, G., \& G. Seal. (2003). A Guide to Australian Folklore: From Ned Kelly to Aeroplane Jelly. Sydney, Kangaroo Press.

Emmison, M. (1997). Transformations of taste: Americanisation, generational change and Australian cultural consumption. Journal of Sociology, 33(3), 322- 43. http://dx.doi.org/10.1177/144078339703300304

Featherstone, M. (ed.) (1990). Global Culture: Nationalism, Globalisation and Modernity. London, Sage.

Hobsbawm, E. (2000). Bandits. London, Weidenfeld and Nicolson.

Hobsbawm, E. (1972). Social Bandits: Reply. Comparative Studies in Society and History, 14(4), 503-5. http://dx.doi.org/10.1017/S0010417500006836

Jones, I. (1995). Ned Kelly: a short life. Port Melbourne, Lothian.

McAllister, I. (1998). Civic Education and Political Knowledge in Australia. Australian Journal of Political Science, 33(1), 7-23. http://dx.doi.org/10.1080/10361149850697

Mannheim, K. (1952). Essays on the Sociology of Knowledge. London, Routledge.

Nixon, A. (1982). 100 Australian Bushrangers, 1789-1901. Adelaide, SA: Rigby. 
UNESCO (2013, May 31). Memory of the World Register. http://www.unesco.org/new/fileadmin/MULTIMEDIA/HQ/CI/CI/pdf/mow/nomination_forms/australia_stor y_of_kelly_gang.pdf.

Pickering, J. (2001). Globalisation: A Threat to Australian Culture? Journal of Australian Political Economy, 48, 46-59.

Seal, G. (2002). Tell 'em I died Game: The Legend of Ned Kelly. Flemington, Victoria, Highland House.

Seal, G. (1996). The Outlaw Legend: A Cultural Tradition in Britain, America and Australia. Cambridge, Cambridge University Press.

Smith, A. (1996). LSE Centennial Lecture: The resurgence of nationalism? Myth and memory in the renewal of nations. British Journal of Sociology, 47(4), 575-98. http://dx.doi.org/10.2307/591074

Stiles, T. J. (2002). Jesse James: Last Rebel of the Civil War. New York: Random House.

Tranter, B. (2007). Political Knowledge and its Partisan Consequences. Australian Journal of Political Science, 42(1), 73-88. http://dx.doi.org/10.1080/10361140601158559

Tranter, B., \& Donoghue, J. (2008). Bushrangers: Ned Kelly and Australian Identity. Journal of Sociology, 44(4), 373-390. http://dx.doi.org/10.1177/1440783308097127

Tranter, \& Donoghue. (2010). Ned Kelly: Armoured Icon. Journal of Sociology, 20(10), 1-19.

West, B. (2001). Crime, Suicide, and the Anti-Hero: "Waltzing Matilda”. Journal of Popular Culture, 35(3), 127-141. http://dx.doi.org/10.1111/j.0022-3840.2001.3503_127.x

Wilson, S., Gibson, R., Meagher, G., Denemark, D., \& Western, M. (2006). Australian Survey of Social Attitudes, 2005. Canberra: Australian National University, ACSPRI Centre for Social Research.

White, R. (1981). Outlaw Gangs of the Middle Border: American Social Bandits. The Western Historical Quarterly, 12(4), 387-408. http://dx.doi.org/10.2307/968851

Yeatman, T. P. (2000). Frank and Jesse James - The Story Behind the Legend. Cumberland House Publishing, Nashville.

\footnotetext{
i The James brothers' stepfather was a physician who resided with their mother on a Missouri farm that was worth $\$ 10,000$ in 1870, and their uncle, George Hite, Sr., was said to have been worth $\$ 100,000$ before losing heavily in the tobacco speculation that forced him into bankruptcy in 1877 (White 1981).

ii In contrast, Billy the Kid became a symbol of the American west following a sensational account of his life and death by his former friend and nemesis, Sheriff Pat Garrett, entitled 'The authentic Life of Billy, the Kid'.

iii Wartime antagonisms generally faded over time, but when Pinkerton agents attacked the home of Jesse and Frank James' mother, she lost an arm and her young son (their half-brother) was killed, it rekindled local hatred for the northern authorities (White 1981).

iv However, Tranter and Donoghue (2010) considered Ned Kelly in relation to national identity, while we are examining knowledge of (popular) culture. Therefore, the expected directional effects of class and ideology are less clear.

$v$ The question is 'Which of the following sources of information would you say you rely on MOST for your news and information? - Newspapers and Internet sites'.

vi The question was 'Who has the majority in the Senate of Federal Parliament?' The correct answer was the Liberal/National Coalition' coded as 1 ; all other responses coded to 0 .

vii That is, for the outlaws scale the $\mathrm{R}^{2}$ for men was .05 and .11 for women, while for the bushrangers dependent variable the $\mathrm{R}^{2}$ was .12 and .19 respectively.

viii In addition to Bob Dylan, Bon Jovi, Billy Joel and Tom Petty have all sang about Billy the Kid, while Woody Guthrie, John Lee Hooker and Hank Williams have all paid homage to Jesse James.

ix Kelly has also been the subject of numerous films, including the first feature film The Story of the Kelly Gang in 1906 and most recently Ned Kelly (2003), academic tomes (e.g. Jones, 1995; Seal, 1996) and novels such as Peter Carey's (2001) Booker Prize winning True History of the Kelly Gang (UNESCO 2013). Kelly also features often in newspaper articles and is a tourist drawcard in the towns associated with his history - known as 'Kelly country'. The Australian government even commemorated the centenary of his death by issuing a postage stamp (Seal, 1996, 148).

$x$ The fact that Homer Simpson wears a Ned Kelly helmet and brandishes a pistol in one episode demonstrates this claim (http://www.ironoutlaw.com/index.html).
}

\section{(cc) $\mathrm{EY}$}

This work is licensed under a Creative Commons Attribution 3.0 License. 